Vol. 4: 445-461.

\title{
Cumulative compaction of a clay loam soil by annually repeated field traffic in autumn
}

\author{
Laura Alakukku and Paavo Elonen \\ Agricultural Research Centre of Finland, Institute of Crop and Soil Science, FIN-31600 Jokioinen, Finland
}

\begin{abstract}
The cumulative effects of annually repeated field traffic on soil properties and barley yield were investigated in a field experiment on clay loam. Experimental traffic was applied with a tractortrailer combination prior to autumn ploughing for four successive years. The trailer single axle load was $5 \mathrm{Mg}$. The loading intensity was 0,100 and $300 \mathrm{Mg} \mathrm{km} \mathrm{ha}^{-1}$, and both standard and low-profile trailer tyres were used. The effect of early summer irrigation on the yield was also studied. The yield and nitrogen uptake of the crop were determined for four successive years. Soil penetrometer resistance was measured annually after the second loading.

The traffic compacted the soil to $0.35 \mathrm{~m}$ depth. On average, soil compaction reduced barley yield by $5 \%$ and nitrogen uptake by $7 \%$. No annual cumulative increase in the compaction depth or yield reductions was found. Probably only the first loading compacted the subsoil, because the soil was drier than field capacity in the $0.2-0.3 \mathrm{~m}$ layer in the following autumns. The use of trailer lowprofile tyres did not reduce the depth of compaction or yield losses. On average, early summer irrigation increased grain yield by $34 \%$ and nitrogen uptake by $25 \%$, but it did not significantly decrease yield or nitrogen uptake reductions due to compaction.
\end{abstract}

Key words: axle load, low-pressure tyres, irrigation

\section{Introduction}

Harvesting time is short in Finland and field work often has to be done on moist soil. The tyre inflation pressure of combines and trailers is usually more than $100 \mathrm{kPa}$ and increasingly their axle load exceeds $5 \mathrm{Mg}$. Thus, there is a risk of subsoil compaction. Field traffic with a single axle load of 6.4-12 Mg and a tyre inflation pressure of $50-300 \mathrm{kPa}$ is found to compact moist mineral soils to depths of $0.3-0.8 \mathrm{~m}$ (Voorhees et al. 1986, van den Akker 1988, Lowery and Schuler 1991, Danfors 1994). Under unfavourable soil conditions, even an axle load of less than $5 \mathrm{Mg}$ compacts the subsoil. Aura (1983) found that spring traffic with an axle load of $3 \mathrm{Mg}$ and tyre inflation pressure of $140 \mathrm{kPa}$ compacted wet clay soil under the $0.2 \mathrm{~m}$ plough layer.

Severely compacted soil may take several years to recover. Despite annual ploughing and frost, severe compaction persists in the plough 
Alakukku, L \& Elonen, P.: Cumulative compaction of a clay loam soil by annually repeated field traffic in autumn

layer of clay soils for three (Alakukku 1996a) or even five years (Håkansson and Danfors 1981). Regular tillage does not loosen the subsoil, and the alleviation of subsoil compaction is usually left to natural processes. Subsoil compaction may thus often persist for a long time. After a single heavy loading in soils with clay contents of $6-85 \%$ it has been reported to persist for 3-11 years despite cropping and deep frost (Blake et al. 1976, Voorhees et al. 1986, Håkansson 1985, Alakukku 1996b).

Since alleviation of severe compaction takes so long, heavy loading repeated in the same place each year may increase soil compactness and yield losses year by year. Arvidsson and Håkanson (1994) reported that annually repeated loading by $350 \mathrm{Mg} \mathrm{km} \mathrm{ha}^{-1}$ on wet clay soils before ploughing caused cumulative yield losses of spring cereals during the first four years. Thereafter the yields reached equilibrium. Gameda et al. $(1987,1994)$ did not observe cumulative yield losses with maize. Field traffic with axle loads of $10-20 \mathrm{Mg}$ and tyre inflation pressures $>300$ $\mathrm{kPa}$ increased, however, the maximum soil density and the depth to which compaction occurred each year during the first three years (Gameda et al. 1987). Repeated field traffic does not, however, always increase soil compaction cumulatively. Alblas et al. (1994) loaded sandy soils with an axle load of $10 \mathrm{Mg}$ twice a year during a period of four years, and did not find any cumulative soil compaction or cumulative silage maize yield losses.

The introduction of large-volume, low-profile tractor and implement tyres allows inflation pressures of $50-100 \mathrm{kPa}$, even with heavy loads. The use of low ground contact pressure machines is expected to allow field traffic with quite heavy axle loads. Danfors (1994) reported, however, that a reduction in inflation pressure from 150 to $50 \mathrm{kPa}$ reduced the compaction of moist clay soils with axle loads $>8 \mathrm{Mg}$ to a maximum depth of $0.3-0.4 \mathrm{~m}$ only. This finding is consistent with theoretical models and earlier measurements showing that the average ground contact pressure has the greatest influence on soil compaction in the topsoil and upper part of the subsoil, but that the axle load is more important deeper in the subsoil (Söhne 1958, Danfors 1974, Bolling 1987, Olsen 1994).

Arvidsson and Håkansson (1994) found that the use of low-profile trailer tyres in their tractor-trailer combination ( $\left.350 \mathrm{Mg} \mathrm{km} \mathrm{ha}{ }^{-1}\right)$, even at an inflation pressure as high as $200 \mathrm{kPa}$, reduced the yield of spring cereals by 5 percentage units less than standard tyres $(500 \mathrm{kPa})$ as a mean of four years. Vermeulen and Perdok (1994) compared a full-size low ground contact pressure farming system with tyre inflation pressures of $40-80 \mathrm{kPa}$ and a common ground pressure system with inflation pressures of 80-240 $\mathrm{kPa}$. On clay loam, the ground pressure did not influence the wheat yield as a mean of four years (Vermeulen and Perdok 1994). Likewise, Chamen et al. (1990) found that winter wheat yields were similar in plots with low $(<50 \mathrm{kPa})$ and high (100-250 kPa) ground contact pressure.

Soil mechanical resistance may prevent roots from penetrating compacted soil when the soil dries up. Some studies indicate that irrigation may relieve this harmful effect. In a year with low precipitation early in the growing season, Elonen (1980) found that irrigation four weeks after sowing reduced yield losses of spring wheat due to clay soil compaction by a $3 \mathrm{Mg}$ axle load just before sowing. Irrigation softened the dry soil and improved root penetration. Likewise, irrigation reduced yield loss of winter wheat in plots with a plough pan (Barraclough and Weir 1988).

In earlier Finnish field experiments, traffic on a single occasion with a tandem axle load of $16 \mathrm{Mg}$ and a tyre inflation pressure of $700 \mathrm{kPa}$ compacted moist clay soil to $0.5 \mathrm{~m}$ depth, and subsoil compaction persisted for at least nine years (Alakukku 1996b). During the harvest, however, field traffic with 5-10 Mg axle loads is repeated each year. Likewise, low-profile tyres allow the tyre inflation pressure to be reduced without decreasing the loading capacity of the tyre. In this study, a field experiment was conducted on clay loam objectives to (1) investigate the cumulative effects of annual transport traffic prior to autumn ploughing on soil and on 
Vol. 4: 445-461.

Table 1. Soil particle size distribution and organic carbon content in the experimental field.

\begin{tabular}{ccccccc}
\hline & & \multicolumn{5}{c}{ Particle size distribution (\%) } \\
\cline { 3 - 6 } $\begin{array}{c}\text { Depth } \\
(\mathrm{m})\end{array}$ & $\begin{array}{c}\text { Organic } \\
\text { carbon (\%) }\end{array}$ & $\begin{array}{c}<2 \\
\text { clay }\end{array}$ & $\begin{array}{c}2-20 \\
\text { silt }\end{array}$ & $\begin{array}{c}20-200 \\
\text { fine sand }\end{array}$ & $\begin{array}{c}200-2000 \mu \mathrm{m} \\
\text { sand }\end{array}$ & Soil type \\
\hline $0-0.2$ & 2.8 & 47 & 28 & 18 & 7 & Clay loam \\
$0.2-0.4$ & 1.1 & 59 & 23 & 14 & 4 & Silty clay \\
\hline
\end{tabular}

barley yield, (2) evaluate the effect of the inflation pressure of trailer tyres on soil compaction, (3) determine the subsoil compaction by a load of no more than $5 \mathrm{Mg}$ on a single axle, and (4) establish whether there is an interaction between compaction and irrigation in early summer, when precipitation is often low in southern Finland.

\section{Material and methods}

\section{Experimental field and treatments}

The field trial was performed at the Agricultural Research Centre of Finland at Jokioinen $\left(60^{\circ} 49^{\prime} \mathrm{N}, 23^{\circ} 28^{\prime} \mathrm{E}\right)$ on a clay loam soil (Table 1, Vertic Cambisol (FAO 1988)) in 1985-1989. The experiment was laid out in a randomized complete-block design with a strip-plot arrangement and four replicates. The main plot treatment (A) was sprinkler irrigation in June with two factor levels: (1) control, no irrigation, and (2) irrigation with $20-30 \mathrm{~mm}$ once or twice. The subplot treatment $(\mathrm{BC})$ was field traffic with a tractortrailer combination in autumn with five factor levels: (1) control, no experimental traffic, (2) $100 \mathrm{Mg} \mathrm{km} \mathrm{ha}^{-1}$, low-profile (LP) tyres on the trailer (inflation pressure $150 \mathrm{kPa}$ ), (3) $100 \mathrm{Mg}$ $\mathrm{km} \mathrm{ha}^{-1}$, standard (ST) tyres on the trailer (350 $\mathrm{kPa}$ ), (4) $300 \mathrm{Mg} \mathrm{km} \mathrm{ha}^{-1}$, LP tyres on the trailer, and (5) $300 \mathrm{Mg} \mathrm{km} \mathrm{ha}^{-1}$, ST tyres on the trailer. The size of the subplots was $3.2 \times 16 \mathrm{~m}$.

The experimental traffic was applied prior to ploughing in four successive autumns. Technical data on the vehicle and annual traffic intensity are shown in Table 2 . With a traffic intens-

Table 2. Axle load and tyre inflation pressure of the tractor-trailer combination and intensity of experimental traffic in 1985 -1988 .

\begin{tabular}{|c|c|c|c|c|c|c|c|c|}
\hline \multirow[b]{2}{*}{ Year } & \multicolumn{2}{|c|}{ Axle load (Mg) } & \multicolumn{2}{|c|}{ Tyre size } & \multicolumn{2}{|c|}{ Inflation pressure $(\mathrm{kPa})$} & \multicolumn{2}{|c|}{$\begin{array}{l}\text { Traffic intensity } \\
\left(\mathrm{Mg} \mathrm{km} \mathrm{ha}^{-1}\right)\end{array}$} \\
\hline & $\begin{array}{l}\text { Tractor } \\
\text { front/rear }\end{array}$ & $\begin{array}{l}\text { Trailer } \\
\text { single }\end{array}$ & $\begin{array}{c}\text { Tractor } \\
\text { front/rear }{ }^{\mathrm{a})}\end{array}$ & $\begin{array}{c}\text { Trailer } \\
\text { LP/ST }^{\text {b) }}\end{array}$ & $\begin{array}{l}\text { Tractor } \\
\text { front/rear }\end{array}$ & $\begin{array}{l}\text { Trailer } \\
\text { LP/ST }\end{array}$ & 100 & 300 \\
\hline \multicolumn{9}{|c|}{ Autumn } \\
\hline 1985 & $4.5^{\mathrm{c})}$ & 5.0 & $11.2-24 / 16.9-36$ & $500 / 55-15.5 / 11.0 / 60-16$ & $140 / 140$ & $150 / 350$ & 119 & 356 \\
\hline 1986 & $-d)$ & $-d)$ & $11.2-24 / 16.9-36$ & $500 / 55-15.5 / 11.0 / 60-16$ & $140 / 140$ & $150 / 350$ & $-d)$ & $-d)$ \\
\hline 1987 & $1.5 / 3.3$ & 5.1 & $11.2-24 / 16.9-36$ & $500 / 55-15.5 /-^{e)}$ & $140 / 140$ & $150 /$-e) $^{e}$ & 122 & 368 \\
\hline 1988 & $1.4 / 2.5$ & 4.5 & $11.2-24 / 16.9-36$ & $500 / 55-15.5 / 11.0 / 60-16$ & $140 / 140$ & $100 / 300$ & 105 & 315 \\
\hline \multicolumn{9}{|c|}{ Spring } \\
\hline 1988 & $0.7 / 3.5$ & & $13.6-28 / 18.4-34$ & & $250 / 200$ & & 53 & 159 \\
\hline
\end{tabular}
a) duals since 1987
b) $\mathrm{LP}=$ low-profile and ST = standard tyres on trailer.
c) total weight of tractor
d) not determined, but the same order as on the other years
e) the soil was too wet for ST treatment 
Alakukku, L \& Elonen, P.: Cumulative compaction of a clay loam soil by annually repeated field traffic in autumn

Table 3. Soil moisture content at the time of experimental traffic and at field capacity $\left(\mathrm{FC}, \psi_{\mathrm{m}}=-10 \mathrm{kPa}\right)$.

\begin{tabular}{|c|c|c|c|c|c|c|}
\hline \multirow{3}{*}{$\begin{array}{l}\text { Depth } \\
\text { (m) }\end{array}$} & \multicolumn{6}{|c|}{ Soil moisture content $(\%, w / w)$} \\
\hline & \multicolumn{4}{|c|}{ Autumn } & \multirow{2}{*}{$\begin{array}{c}\text { Spring } \\
1988\end{array}$} & \multirow[b]{2}{*}{$\mathrm{FC}$} \\
\hline & 1985 & 1986 & 1987 & 1988 & & \\
\hline $0-0.1$ & 33 & 34 & 36 & 32 & 21 & 34 \\
\hline $0.1-0.2$ & 34 & 32 & 34 & 33 & 28 & 32 \\
\hline $0.2-0.3$ & 31 & 28 & 28 & 27 & 32 & 33 \\
\hline $0.3-0.4$ & 28 & 32 & 31 & 31 & 33 & 31 \\
\hline
\end{tabular}

Table 4. Irrigation date, water dose per irrigation and monthly rainfall deficiency in early summer during the experimental period.

\begin{tabular}{|c|c|c|c|c|c|c|}
\hline \multirow[b]{2}{*}{ Year } & \multirow[b]{2}{*}{ Irrigation date } & \multirow[b]{2}{*}{ Water dose $(\mathrm{mm})$} & \multicolumn{4}{|c|}{ Rainfall deficiency $(\mathrm{mm})^{\mathrm{a})}$} \\
\hline & & & May & June & July & Total \\
\hline 1986 & 17.6. & 22 & 1 & 121 & 35 & 157 \\
\hline 1987 & 13.7. & 22 & 10 & -21 & 52 & 41 \\
\hline 1988 & 9.6. and 17.6. & $33^{\text {b) }}$ and 29 & 28 & 79 & -5 & 102 \\
\hline 1989 & 14.6 and 22.6 . & 18 and 33 & 29 & 86 & 41 & 156 \\
\hline
\end{tabular}

a) determined by the Finnish Meteorological Institute

b) $5,4 \mathrm{~mm}$ as precipitation

ity of $100 \mathrm{Mg} \mathrm{km} \mathrm{ha}^{-1}$, trailer wheel tracks with low-profile tyres covered the plot area completely once. At the time of field traffic, the soil was at field capacity moisture content or wetter in the $0.2 \mathrm{~m}$ plough layer (Table 3 ). Except in the first year, the subsoil was clearly drier at 0.2 $0.3 \mathrm{~m}$ depth ( $80-85 \%$ of field capacity). In autumn 1987, the plough layer was soft and could only bear the trailer with low-profile tyres; the standard tyre plots were not loaded. These plots were loaded with a tractor just before seedbed preparation in spring 1988 (Table 2) when the topsoil $(0-0.15 \mathrm{~m})$ was dry and the subsoil at field capacity (Table 3 ). The spring loading, covering the plot area completely, was 53 and 159 $\mathrm{Mg} \mathrm{km} \mathrm{ha}{ }^{-1}$ in field traffic levels 3 and 5, respectively.

The crop was spring barley (Hordeum vulgare, variety Pomo in 1986 and Kustaa since 1987) with an annual application of $110-120 \mathrm{~kg}$ $\mathrm{N} \mathrm{ha}^{-1}$ as NPK fertilizer, placed with a combidrill. For details of the farming, see Alakukku (1996a). In these operations the axle load of machines was $0.9-2.3 \mathrm{Mg}$, the tyre inflation pres- sure $100-140 \mathrm{kPa}$ and the annual loading 118 $\mathrm{Mg} \mathrm{km} \mathrm{ha}{ }^{-1}$.

Irrigation was carried out when the soil water content in control plots, measured by the gypsum block method at $0.15 \mathrm{~m}$ depth, decreased to below $50 \%$ of the plant-available water capacity (Alakukku and Elonen 1994). Plots were usually irrigated in June (Table 4). In 1987, the growing season was, however, cold and rainy and the plots were irrigated in July with rotary sprinklers. The water doses per irrigation are shown in Table 4.

\section{Soil and plant measurements}

Table 5 lists the measurements carried out during the experimental period. Soil penetrometer resistance was measured to $0.52 \mathrm{~m}$ depth in $0.035 \mathrm{~m}$ increments using a penetrometer equipped with a $12.8 \mathrm{~mm}$ diameter $\left(30^{\circ}\right.$ angle) cone mounted on a relieved shaft and driven at approximately $0.03 \mathrm{~m} \mathrm{~s}^{-1}$ (Andersson et al. 1980). Results are given as the median of measured rep- 
Vol. 4: 445-461.

Table 5. Measurements made during the experimental period.

\begin{tabular}{lcc}
\hline Measurement & Year & $\begin{array}{c}\text { Field traffic } \\
\text { levels }\end{array}$ \\
\hline Soil penetrometer resistance & 1987 & all \\
& 1988 & 1 and $5^{\text {a) }}$ \\
Soil dry bulk density & 1989 & all \\
Tyre/soil contact area & 1989 & all \\
Grain yield & 1990 & all \\
Seed moisture content at harvest & $1986-89$ & all \\
Nitrogen yield & $1986-89$ & all \\
Crop lodging & 1987 & all \\
\hline
\end{tabular}

a) 1 = no compaction, $5=300 \mathrm{Mg} \mathrm{km} \mathrm{ha}^{-1}$, standard tyres (compacted also in spring 1988)

b) all tyres on a rigid surface and during the first and third loading on the field

licates at each depth in a plot. The number of replicates per plot was ten except in 1987 when it was five. Soil dry bulk density was determined by the gravimetric method in 1989. Soil samples were taken from a depth of $0.03-0.48 \mathrm{~m}$ at $0.05 \mathrm{~m}$ intervals with the soil core sampler described by Heinonen (1960). Three replicates taken from each depth in a plot were combined as a plot sample with a volume of $300 \mathrm{~cm}^{3}$. For soil moisture content during measurements and sampling see Alakukku and Elonen (1994).

The tyre/soil contact areas of the tractor-trailer combination were determined in 1990 under soil conditions similar to those during the experimental autumns. The static contact area between soil and each tyre was estimated using a technique outlined by Smith and Dickson (1990). The determination was made in two positions in the field and on a rigid surface with a total of four replicates. The average ground contact pressure was calculated by dividing the wheel load by the ground contact area.

An area of $29 \mathrm{~m}^{2}$ was harvested annually from the centre of each experimental plot. The grain yield is presented at $15 \%$ moisture content. The grain moisture content at harvest was calculated on the basis of the dry matter as determination described by Alakukku and Elonen (1995). The nitrogen content of the dry matter was measured by the near infrared reflectance technique (McGuire 1986). The area of lodged crop was evaluated as percent of the total area of a plot.

The significance of differences in soil penetrometer resistance, dry bulk density, grain yield and nitrogen yield data were tested with analysis of variance using the General Linear Model procedure of SAS statistical programs (SAS 1990). Treatment means were tested at the $95 \%$ probability level by using the contrast statement (Milliken and Johnson 1984). If an interaction was found between irrigation and field traffic treatments, the contrast statement was performed for both irrigation levels separately.

\section{Results}

\section{Average ground contact pressure and calculated vertical normal stress}

Table 6 gives the average ground contact results and the calculated average ground contact pressures. The measurements of ground contact areas were rough but the data on various tyres are comparable. The ground contact pressure was higher on the rigid surface than on the field, where tyre sinkage reduced the average ground pressure. The average rut depth with wide tyres was $0.02 \mathrm{~m}$ and with narrow tyres $0.11 \mathrm{~m}$. It should be emphasized that stress is not uniformly distributed over the ground contact area. Thus, the maximum ground contact pressure at the centre of the contact area on soft soil may be as much as twice the estimated average ground pressure.

On the basis of an average ground contact pressure (q) of $50 \mathrm{kPa}$ and pressures listed in Table 6, the stresses to which the soil was subjected by tyres are simulated in Figure 1. The soil vertical normal stress $\left(\sigma_{z}\right)$ beneath the centre of a uniformly loaded circular ground contact area was calculated as a function of depth (z) using the following equation reported by Söhne (1958): 
Alakukku, L \& Elonen, P.: Cumulative compaction of a clay loam soil by annually repeated field traffic in autumn

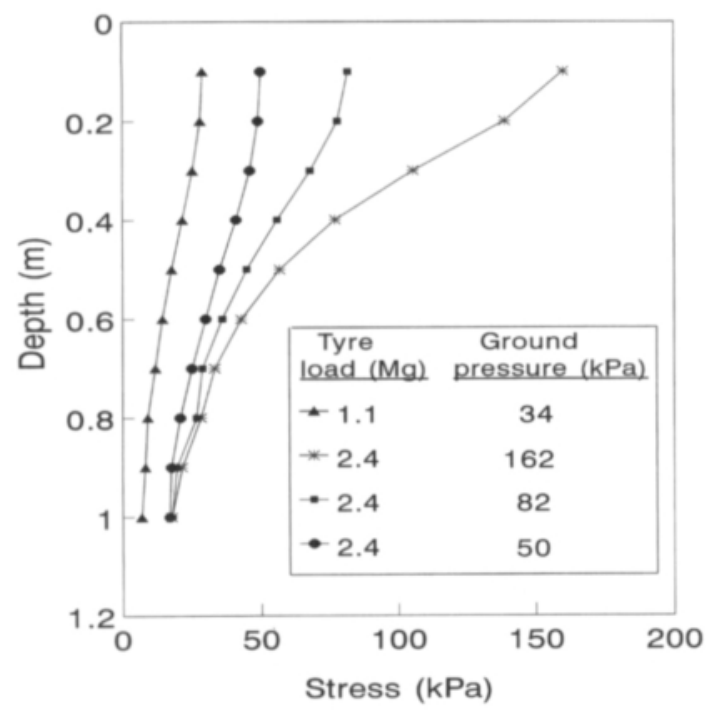

Fig. 1. Calculated vertical normal stress as a function of depth beneath the centre of a circular and uniformly loaded ground contact area.

$$
\sigma_{\mathrm{z}}=\mathrm{q}\left(1-\cos ^{\mathrm{v}} \alpha\right)(1)
$$

Angle $(\alpha)$ characterizes the depth of the loaded point below the centre of the ground contact area. Because the loaded soil was moist, a concentration factor $(v)$ of five was used. In this calculation the soil is considered as a homogeneous, isotropic, semi-infinite, elastic medium. In the field, these conditions are seldom fulfilled, and the contact area is not circular. On the basis of this calculation, the vertical stresses due to different tyres can, however, be compared with each other.

\section{Soil penetrometer resistance and dry bulk density}

Figures 2-4 show the soil penetrometer resistance after the second, third and fourth loading. Figure 4 shows the soil dry bulk density after four repeated loadings. Results are given as means of irrigation levels. Irrigation did not reduce the differences in soil properties measured in autumn between compaction levels. In 1989, the soil penetrometer resistance was, however, greater in unirrigated than in irrigated plots in the $0.18-0.38 \mathrm{~m}$ layer since the soil was drier in unirrigated plots at a depth of $0.28-0.38 \mathrm{~m}$ (Alakukku and Elonen 1994).

To minimize the error due to soil moisture content, an attempt was made to measure the penetrometer resistance when the soil was near field capacity (FC). In 1988, dryness (70\% of FC) increased soil penetrometer resistance at $0-0.15 \mathrm{~m}$ depth, however, underlining the difference between treatments (Figure 3). In 1989, the topsoil was damped by rain in autumn to $0.28 \mathrm{~m}$ depth (Alakukku and Elonen 1994). Below this depth, the soil moisture content was $90 \%$ of FC. Moreover, soil dryness increased penetrometer resistance more in plots loaded by $300 \mathrm{Mg} \mathrm{km}$ $\mathrm{ha}^{-1}$ than in other plots in the $0.28-0.32 \mathrm{~m}$ layer (Figure 4), thus complicating the evaluation of a cumulative increase in the intensity of compaction from 1987 to 1989.

Both soil parameters used, that is, penetrometer resistance and dry bulk density, give less

Table 6. Average ground contact pressure of the tractor-trailer combination used in experimental traffic in autumn 1990.

\begin{tabular}{lccccc}
\hline & & \multicolumn{2}{c}{ Average ground contact pressure $(\mathrm{kPa})$} \\
\cline { 5 - 6 } & & $\begin{array}{c}\text { Tyre load } \\
(\mathrm{Mg})\end{array}$ & $\begin{array}{c}\text { Inflation } \\
\text { pressure } \\
(\mathrm{kPa})\end{array}$ & $\begin{array}{c}\text { Rigid } \\
\text { surface }\end{array}$ & Stubble field \\
\cline { 5 - 6 } & 0.75 & 100 & 142 & 30 & 3rd loading \\
\hline $\begin{array}{l}\text { Tractor front } \\
\text { Tractor rear }\end{array}$ & 1.05 & 120 & 62 & 29 & 40 \\
Trailer & 2.4 & 150 & 123 & 82 & 93 \\
Low-profile & 2.4 & 350 & 367 & 162 & 167 \\
Standard & & & & & 59 \\
\hline
\end{tabular}


Vol. 4: 445-461.
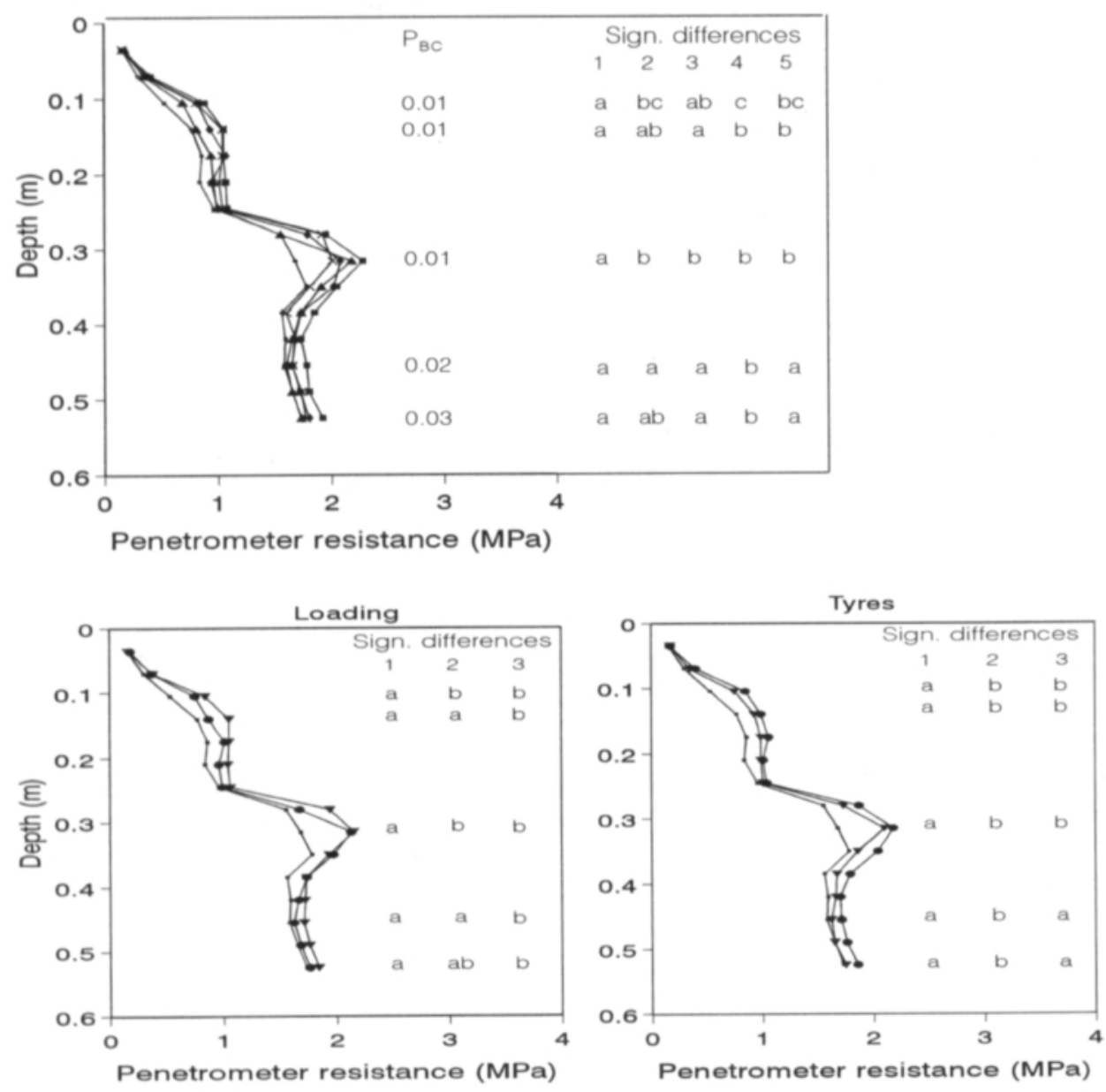

\begin{tabular}{|l|}
\hline Field traffic \\
(1) Control \\
(2) $100 \mathrm{Mg} \mathrm{km} \mathrm{ha}^{-1}, 150 \mathrm{kPa}$ \\
(3) $100 \mathrm{Mg} \mathrm{km} \mathrm{ha}^{-1}, 350 \mathrm{kPa}$ \\
(4) $300 \mathrm{Mg} \mathrm{km} \mathrm{ha}^{-1}, 150 \mathrm{kPa}$ \\
$\times$ (5) $300 \mathrm{Mg} \mathrm{km} \mathrm{ha}^{-1}, 350 \mathrm{kPa}$ \\
\hline
\end{tabular}

\begin{tabular}{|c|c|c|}
\hline & $\begin{array}{l}\text { Loading } \\
\left(\mathrm{Mg} \mathrm{km} \mathrm{ha}^{-1}\right)\end{array}$ & $\begin{array}{c}\text { Trailer tyres } \\
(\mathrm{kPa}) \\
\end{array}$ \\
\hline I (1) & 0 & 0 \\
\hline${ }^{\bullet}(2)$ & 100 & 150 \\
\hline (3) & 300 & 350 \\
\hline
\end{tabular}

Fig. 2. Soil penetrometer resistance at field capacity as a function of depth in loaded treatments in autumn 1987. Treatment means for a given depth are followed by the same letters and those with no letters are not significantly different $\left(\mathrm{P}_{\mathrm{BC}} \leq 0.05\right)$.

information on the effects of soil structure on drainage and crop growth than parameters sensitive to changes in pore size distribution and the continuity of pores. Penetrometer resistance was nevertheless used because it can be determined faster than parameters requiring soil 


\section{AGRICULTURAL SCIENCE IN FINLAND}

Alakukku, L \& Elonen, P.: Cumulative compaction of a clay loam soil by annually repeated field traffic in autumn
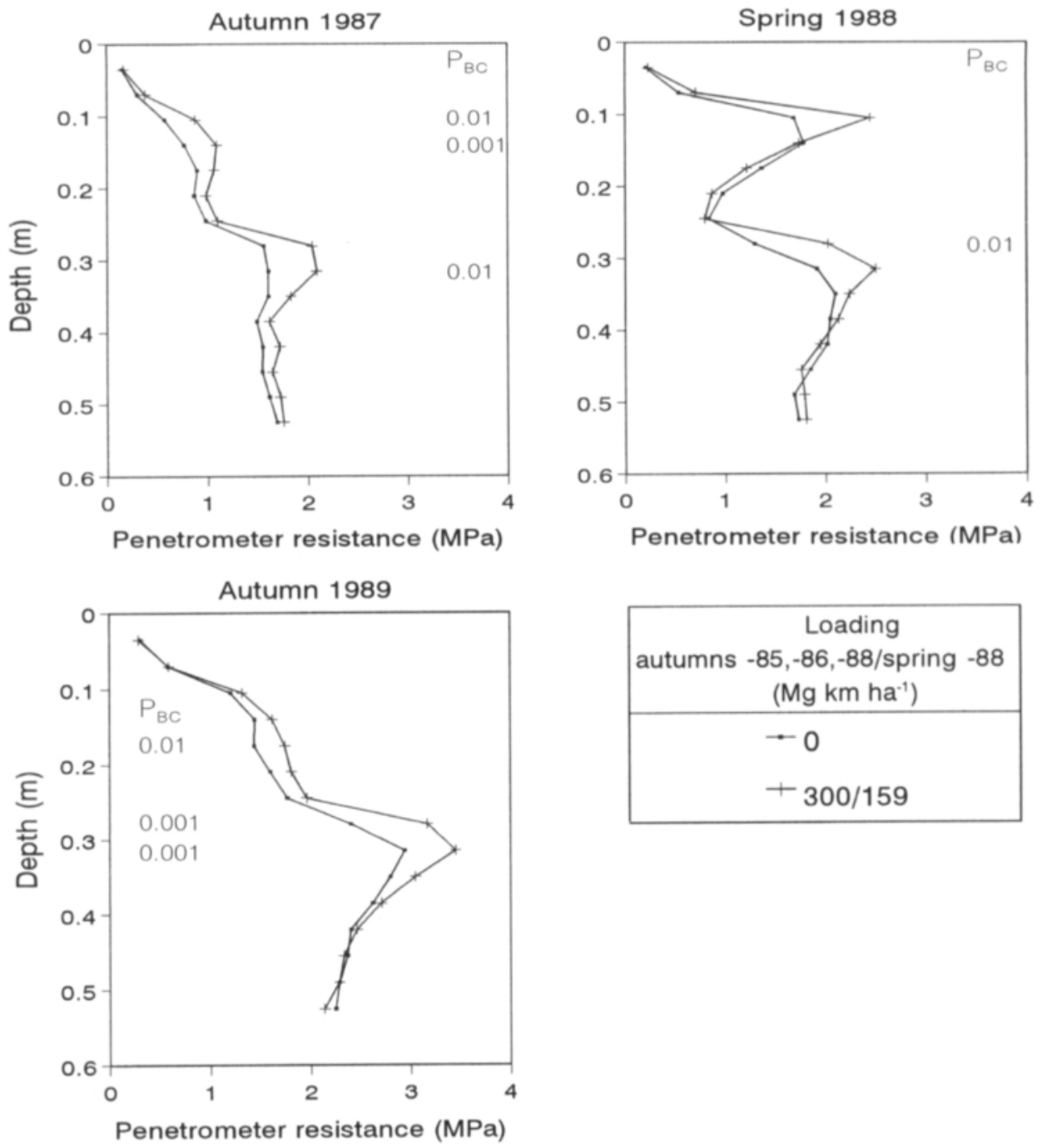

\begin{tabular}{|c|}
\hline Loading \\
autumns $-85,-86,-88 /$ spring -88 \\
$\left(\mathrm{Mg} \mathrm{km} \mathrm{ha}^{-1}\right)$ \\
\hline-0 \\
$+300 / 159$ \\
\hline
\end{tabular}

Fig. 3. Soil penetrometer resistance as a function of depth in the control and in a loaded treatment in $1987-1989$. The loading was $300 \mathrm{Mg} \mathrm{km} \mathrm{ha}^{-1}$ with trailer standard tyres in autumns 1985,1986 and 1988 , and $159 \mathrm{Mg} \mathrm{km} \mathrm{ha}^{-1}$ with a tractor in spring 1988. During the measurements, soil was at field capacity (FC) except to $0.15 \mathrm{~m}$ depth ( $70 \%$ of FC) in 1988 and below $0.28 \mathrm{~m}$ depth (90\% of FC) in 1989. Treatment means with no $\mathrm{P}_{\mathrm{BC}}$ value are not significantly different at the 0.05 level.

sampling and laboratory analyses. Thus, more measurements could be made annually. Likewise, penetrometer resistance was more sensitive to soil compaction than dry bulk density (Figure 4) as reported by Voorhees et al. (1978). For instance, in the $0.13-0.23 \mathrm{~m}$ layer in 1989 , loading with $300 \mathrm{Mg} \mathrm{km} \mathrm{ha}^{-1}$ increased penetrometer resistance by $15 \%$ but dry bulk density by

Fig. 4. Soil penetrometer resistance and dry bulk density as a function of depth in loaded treatments in autumn 1989. Soil was at field capacity (FC) to $0.28 \mathrm{~m}$ depth; below that at $90 \%$ of FC. Treatments and significance levels as in Fig. 2. 
Vol. 4: 445-461.
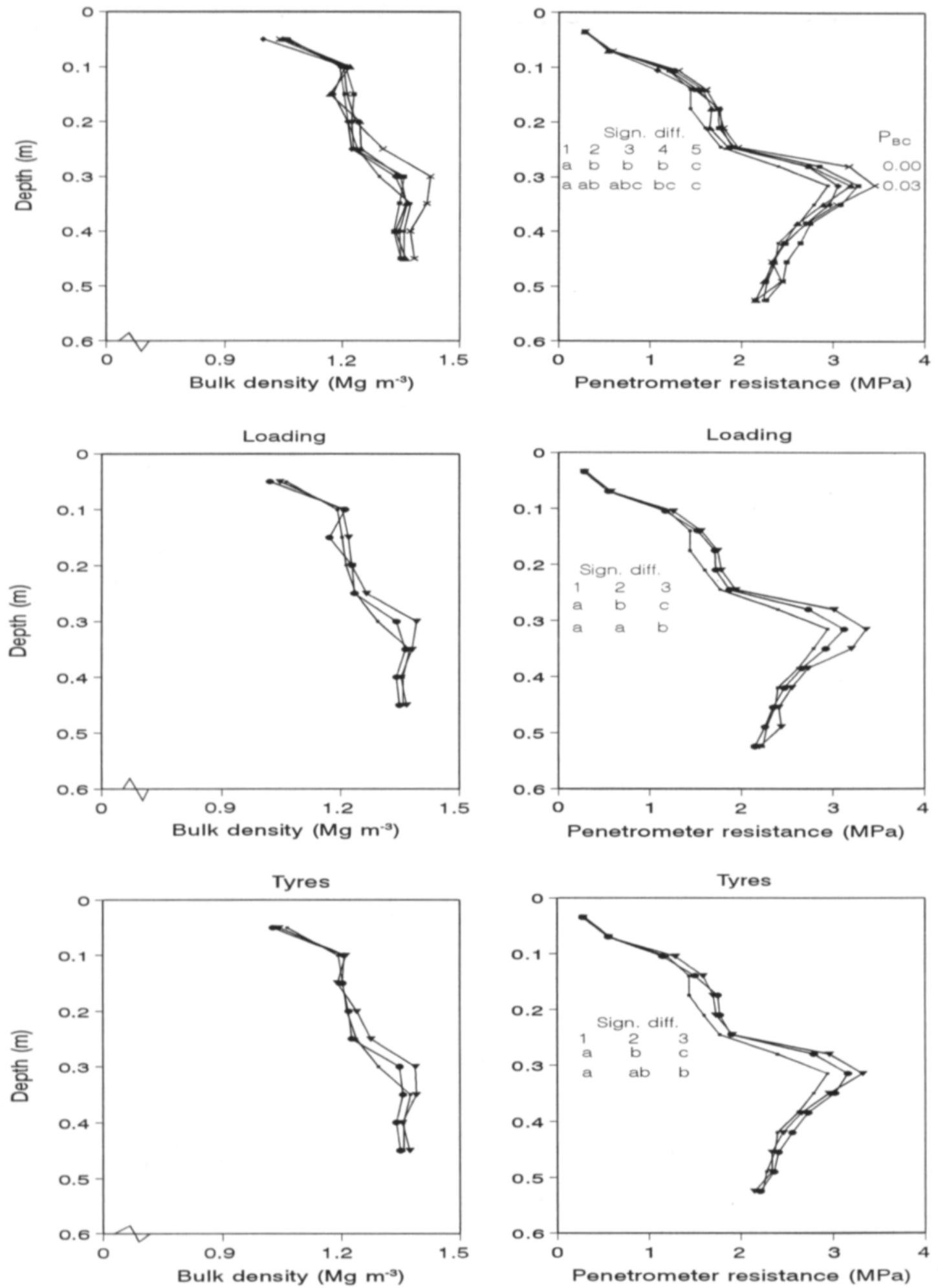


\section{AGRICULTURAL SCIENCE IN FINLAND}

Alakukku, L \& Elonen, P.: Cumulative compaction of a clay loam soil by annually repeated field traffic in autumn

Table 7. Mean relative grain and nitrogen yields as average of irrigation levels in four experimental years $(\mathrm{control}=100)$.

\begin{tabular}{|c|c|c|c|c|c|c|c|c|c|c|}
\hline \multirow[b]{3}{*}{ Year } & \multicolumn{5}{|c|}{ Grain yield $(\%)$} & \multicolumn{5}{|c|}{ Nitrogen yield $(\%)$} \\
\hline & \multicolumn{2}{|c|}{ Loading $\left(\mathrm{Mg} \mathrm{km} \mathrm{ha}^{-1}\right)$} & \multicolumn{2}{|c|}{ Trailer tyres } & \multirow[b]{2}{*}{ Mean } & \multicolumn{2}{|c|}{ Loading $\left(\mathrm{Mg} \mathrm{km} \mathrm{ha}^{-1}\right)$} & \multicolumn{2}{|c|}{ Trailer tyres } & \multirow[b]{2}{*}{ Mear } \\
\hline & 100 & 300 & LP & ST & & 100 & 300 & LP & ST & \\
\hline 1986 & 92 & 89 & 90 & 89 & 90 & 91 & 89 & 91 & 89 & 91 \\
\hline $1987^{\mathrm{a})}$ & 98 & 96 & 97 & 98 & 97 & 97 & 94 & 96 & 96 & 96 \\
\hline 1988 & 98 & 95 & 93 & $100^{b)}$ & 97 & 96 & 94 & 93 & $97^{b)}$ & 95 \\
\hline 1989 & 96 & 95 & 95 & 95 & 95 & 97 & 93 & 95 & 94 & 95 \\
\hline Mean & 96 & 94 & 94 & $94^{\text {c) }}$ & 95 & 95 & 93 & 94 & $93^{\text {c) }}$ & 94 \\
\hline
\end{tabular}

$\mathrm{LP}=$ low-profile and ST $=$ standard tyres on trailer.
a) crop lodged (Table 8)
b) soil was compacted in spring
c) results from 1988 exeluded

Table 8. Mean lodging of barley (\% of plot area) three weeks before harvesting in 1987. Irrigation was carried out in July.

\begin{tabular}{|c|c|c|c|c|c|c|c|c|c|c|}
\hline \multirow[b]{2}{*}{ Irrigation } & \multirow[b]{2}{*}{ Control } & \multicolumn{2}{|c|}{$100 \mathrm{Mg} \mathrm{km} \mathrm{ha}^{-1}$} & \multicolumn{2}{|c|}{$300 \mathrm{Mg} \mathrm{km} \mathrm{ha}^{-1}$} & \multirow[b]{2}{*}{ Mean $_{\text {Imig. }}$} & \multicolumn{2}{|c|}{ Loading $\left(\mathrm{Mg} \mathrm{km} \mathrm{ha}^{-1}\right)$} & \multicolumn{2}{|c|}{ Trailer tyre: } \\
\hline & & LP & ST & LP & ST & & 100 & 300 & LP & ST \\
\hline No & 62 & 50 & 56 & 36 & 34 & 48 & 53 & 35 & 43 & 45 \\
\hline Irrigated & 54 & 40 & 50 & 42 & 16 & 40 & 45 & 29 & 41 & 33 \\
\hline Mean & 58 & 45 & 53 & 39 & 25 & 44 & 49 & 32 & 42 & 39 \\
\hline
\end{tabular}

$\mathrm{LP}=$ low-profile and $\mathrm{ST}=$ standard trailer tyres

only $1 \%$ compared with control treatment (Figure 4). No statistically significant differences in dry bulk density were observed. The measured values varied greatly and three replicates in a plot were too few to allow reliable evaluation of the effects of loading on dry bulk density.

\section{Barley yield and nitrogen uptake}

Figures 5 and 6 and Table 7 show the grain and nitrogen yields during the experimental period. The moisture content at harvest is not reported because it was little affected by autumn com- paction (Alakukku and Elonen 1994). This result differs from those of Alakukku and Elonen (1995), who found that clay soil compaction with a $19 \mathrm{Mg}$ tandem axle load reduced the moisture content when barley was harvested by accelerating plant ripening in compacted plots several years after compaction.

In 1987, the lodging of barley and in 1988 the spring compaction of plots with standard trailer tyres complicated the interpretation of results. Soil compaction reduced crop lodging (Table 8), as Lipiec et al. (1990) and Alakukku and Elonen (1995) also observed with small grain cereals. Thus, lodging masked the negative ef-

Fig. 5. Barley yield at $15 \%$ moisture content in individual years and as a mean for the four-year experimental period. Treatment means followed by the same letters and those with no letters or $\mathrm{P}_{\mathrm{A}}$ values are not significantly different $(\mathrm{P} \leq 0.05)$. 
Vol. 4: 445-461.
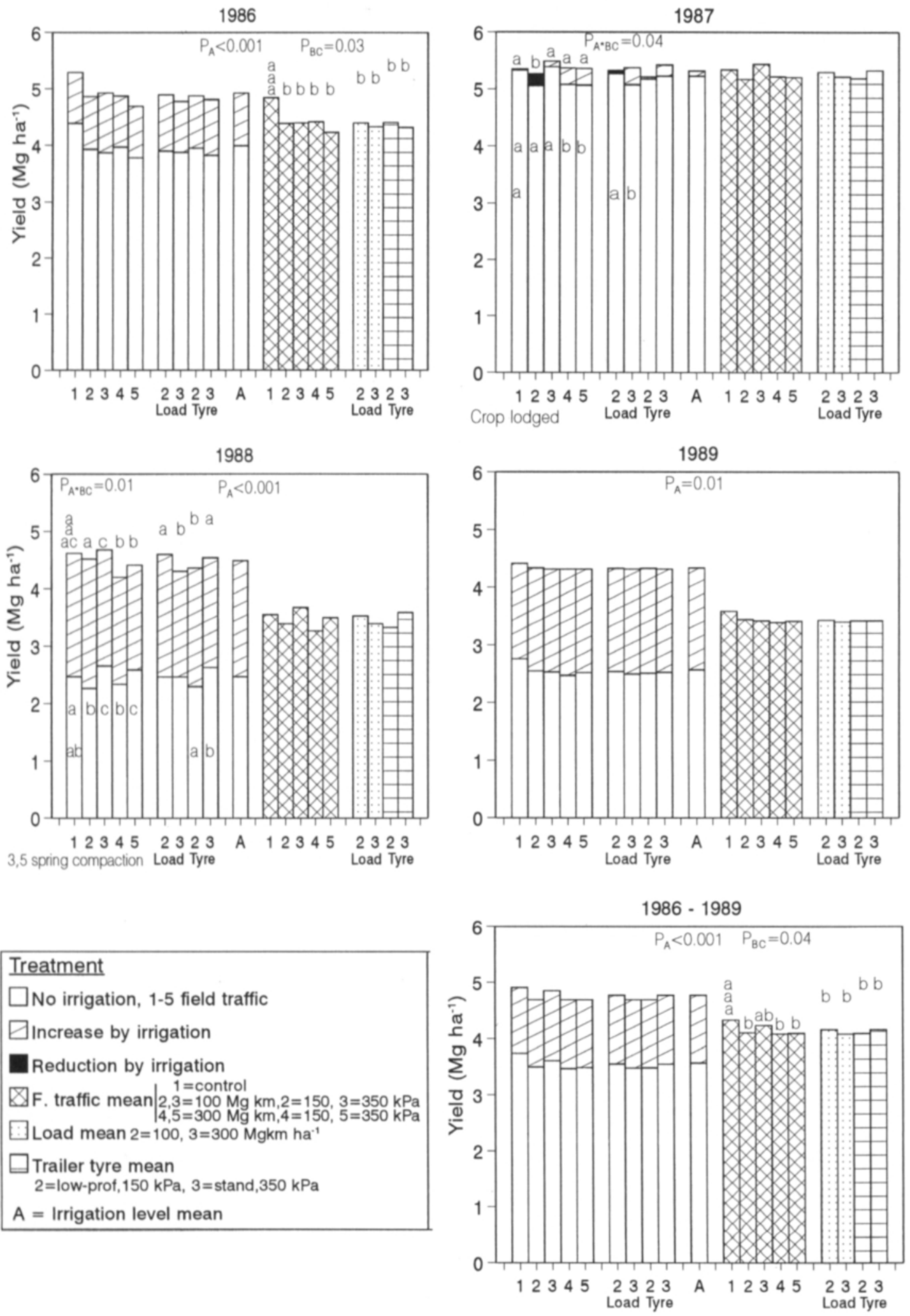
Alakukku, L \& Elonen, P.: Cumulative compaction of a clay loam soil by annually repeated field traffic in autumn

fects of soil compaction on crop growth. Likewise, irrigation in a cold and rainy year reduced crop lodging by hindering crop growth. In June, for instance, the rainfall deficiency was $-21 \mathrm{~mm}$ (Table 4) and the mean temperature was $1.7^{\circ} \mathrm{C}$ lower than average. In 1986, 1988 and 1989, the rainfall deficiency in June was more than $78 \mathrm{~mm}$ (Table 4) and the drought at the beginning of the growing season affected crop growth in unirrigated plots more than did soil loading in autumn (Figures 5 and 6).

In 1988, spring compaction increased the yield by $6 \%$ in plots with no irrigation (Figure 5). Barley emerged best and fastest in plots compacted in spring. Control plots and plots compacted in autumn (low-profile tyres) and spring had 355,334 and 375 seedlings $\mathrm{m}^{-2}$, respectively. Tractor traffic prior to seedbed preparation sheared the aggregates near the dry soil surface. Thus, in spring-compacted plots, the amount of aggregates with a diameter smaller than $2 \mathrm{~mm}$ was 7 and 8 percentage units higher than in control and autumn-compacted plots, respectively, in the $0-0.03 \mathrm{~m}$ layer. The finer seedbed in plots compacted in spring probably reduced evaporation and gave good soil-seed contact, thus improving the germination and initial growth of barley in dry, early summer (Table 4). In irrigated plots, yield was not increased by spring compaction (Figure 5). The control plots with slow initial growth benefited from irrigation more than fast growing plots compacted in spring.

\section{Discussion}

Field traffic prior to autumn ploughing with a single-axle load of $5 \mathrm{Mg}$ and a tyre inflation pressure of $150 \mathrm{kPa}$ compacted the subsoil of clay loam to $0.35 \mathrm{~m}$ depth. When the field traffic was applied, the soil moisture content was near or higher than FC in the $0.2 \mathrm{~m}$ plough layer each autumn but in the subsoil only in the first year. Wetness probably made the soil more sensitive to loading. Akram and Kemper (1979) reported that the maximum compaction of mineral soils is reached when the soils are loaded at a moisture content near FC. With the same loading, wet mineral soil is compacted more and deeper than dry soil (Aura 1983, Gameda et al. 1987).

Despite ploughing to $0.2 \mathrm{~m}$, frost and cropping, compaction due to autumn loading persisted for at least one year at $0.1-0.2 \mathrm{~m}$ depth as shown by Voorhees et al. (1978) on clay loam. In contrast, Elonen (1980) and Aura (1983) reported that compaction in the plough layer of clay soils due to traffic with a $3 \mathrm{Mg}$ axle load prior to seedbed preparation was relieved to the next spring. As was assumed, compaction persisted in the subsoil even though the soil was cropped and the frost penetrated each year to $0.4-0.5 \mathrm{~m}$ depths (Alakukku and Elonen 1994).

Subsoil compaction persists for a very long time (Blake et al. 1976, Voorhees et al. 1986, Håkansson 1985). Under Finnish conditions, subsoil compaction persists for at least nine years in clay soils (Alakukku 1996b), and increases the risk of long lasting soil degradation. The present results indicated that the load on a single axle must be less than $5 \mathrm{Mg}$ under moist soil conditions to avoid soil compaction below normal tillage depth. Elsewhere, axle load limits of 4 to $6 \mathrm{Mg}$ on moist soils have been recomended (Danfors 1974 and 1994, Voorhees and Lindström 1983, Petelkau 1984), even when the tyre inflation pressure is $50 \mathrm{kPa}$ (Danfors 1994). On Finnish farms, the risk of subsoil compaction is severe during harvest, slurry spreading and tillage. With the machines used in these operations, single-axle loads of $5 \mathrm{Mg}$ and a tyre inflation pressure of $100 \mathrm{kPa}$ are often exceeded when the soil is moist.

No cumulative increase in the depth of soil compaction or yield losses due to annually re-

Fig. 6. Nitrogen yield harvested in the grain in individual years and as a mean for the four-year experimental period. Treatment means followed by the same letters and those with no letters or $\mathrm{P}_{\mathrm{A}}$ values are not significantly different $(\mathrm{P} \leq 0.05)$. 
Vol. 4: 445-461.
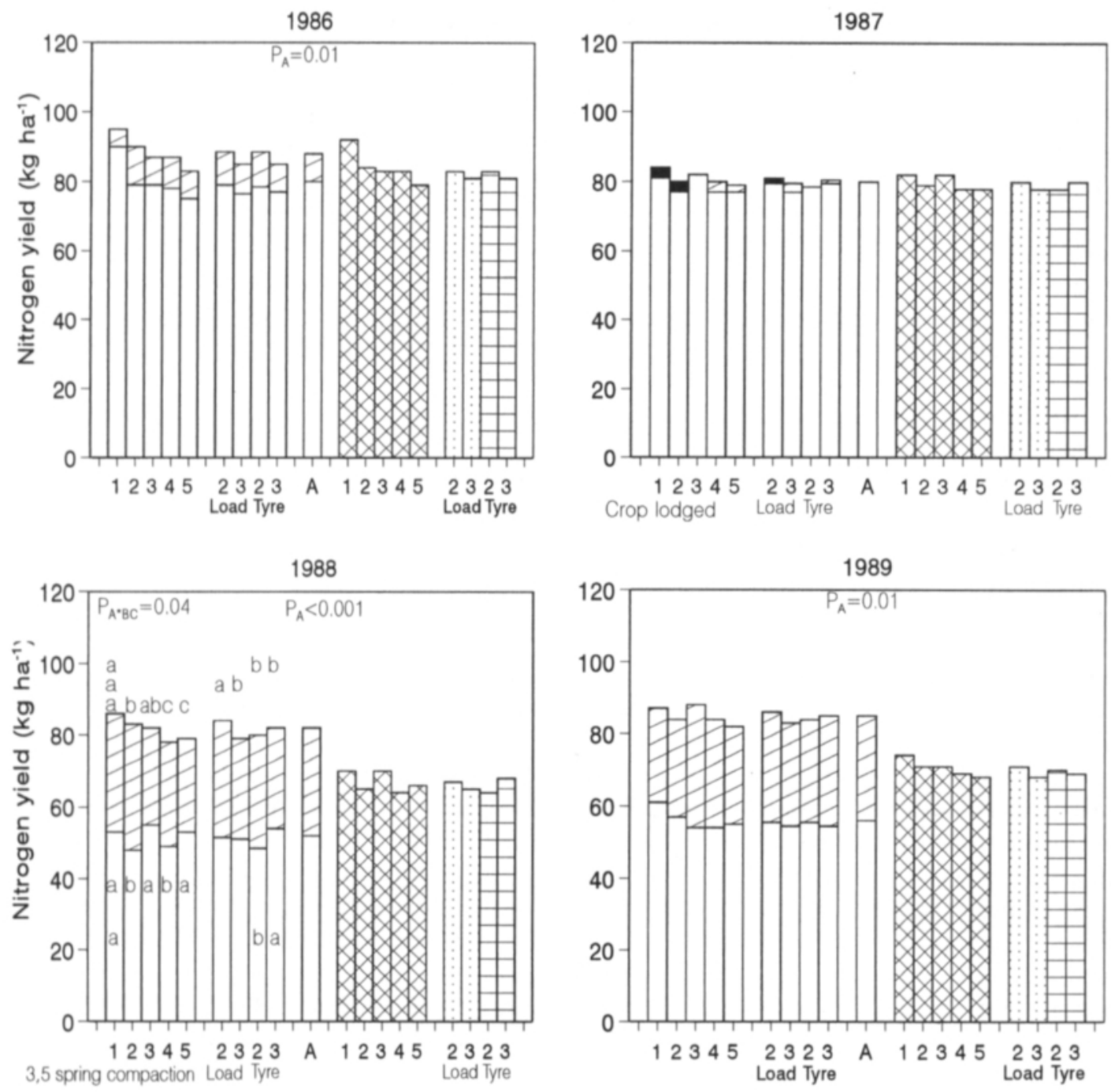

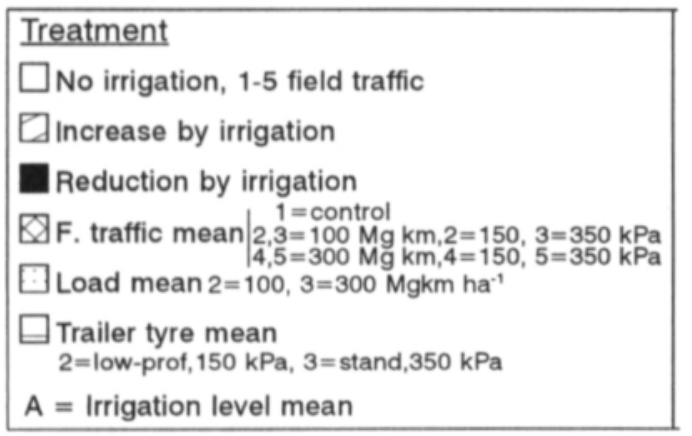

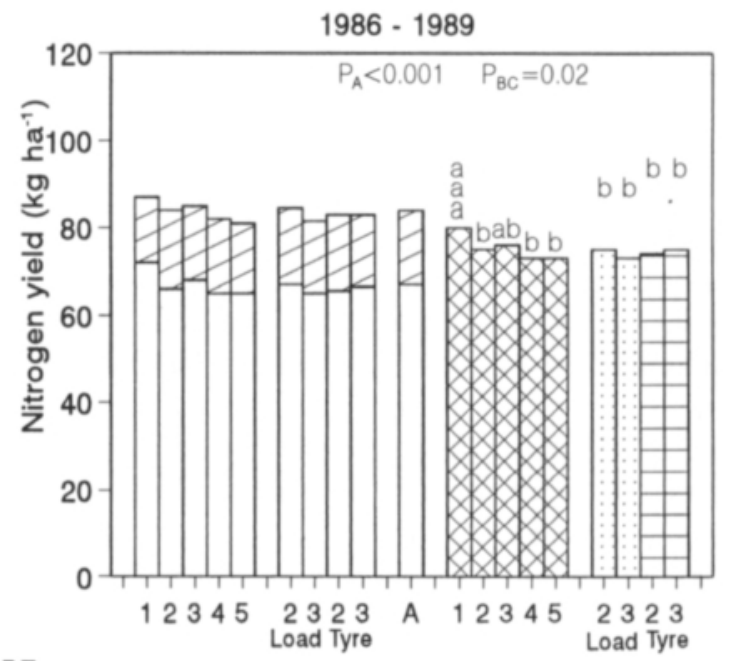


Alakukku, L \& Elonen, P.: Cumulative compaction of a clay loam soil by annually repeated field traffic in autumn

peated field traffic were found, even though the earlier compaction was not relieved before the new loading. Gameda et al. (1987) reported that the intensity and depth of clay soil compaction were increased year by year by annually repeated heavy loading on wet soil. Likewise, yield losses of spring cereals due to an annual loading of $350 \mathrm{Mg} \mathrm{km} \mathrm{ha-1}$ on wet clay soils before autumn ploughing increased cumulatively during the first four years (Arvidsson and Håkansson 1991). In the present study, the possible cumulative effects of repeated loading on soil could have been evaluated better had the soil properties been measured before and after each loading. Soil penetrometer resistance was measured for the first time after two loadings. The subsoil had probably compacted primarily at the first loading because the soil was drier than FC in the $0.2-0.3 \mathrm{~m}$ layer in the following autumns. Therefore, the effects of the later loadings were too slight to affect crop yield and to be determined with the penetrometer.

Reducing trailer tyre inflation pressure from 350 to $150 \mathrm{kPa}$ by increasing the tyre size did not lessen compaction in the plough layer, even though it reduced the average ground contact pressure from 162 to $82 \mathrm{kPa}$. Other workers have had contrary results (Campbell et al. 1984, Koger et al. 1985, Bolling 1987), but in their experiments the soil was compacted by a single tyre only. Here, on the other hand, both tractor and trailer compacted the soil, thus reducing the difference between different trailer tyres. Low-profile tyres (width $500 \mathrm{~mm}$ ) also compacted a greater area than standard tyres (width $275 \mathrm{~mm}$ ), which may reduce the difference between tyres as found by Chamen et al. (1985). Hence the use of low-profile tyres propably did not reduce the yield or nitrogen uptake losses of barley. Chamen et al. (1990) and Vermeulen and Perdok (1994) found that the use of a low tyre inflation pressure farming system (below $80 \mathrm{kPa}$ ) for four years did not affect wheat yield any differently from a high ground pressure system (80-250 $\mathrm{kPa})$. By contrast, Arvidsson and Håkansson (1994) found that field traffic with an intensity of $350 \mathrm{Mg} \mathrm{km} \mathrm{ha-1}$ prior to autumn ploughing reduced the yield of small grain cereals by $10 \%$ when the tyre inflation pressure was $200 \mathrm{kPa}$, and by $15 \%$ when the inflation pressure was 500 $\mathrm{kPa}$ as a mean of four years.

The use of low-profile tyres on the trailer did not reduce the depth of soil compaction, which is consistent with the results of Danfors (1994). The trend in the present results, as in those reported by Alakukku and Elonen (1994) was a reduction in cumulative soil compaction in the plough sole $(0.28-0.32 \mathrm{~m})$, as found also by Chamen et al. (1990). According to the theoretical calculation, the vertical normal stress below the low-profile trailer tyres was markedly less than that of standard tyres to a depth of $0.3 \mathrm{~m}$. At $0.5 \mathrm{~m}$ depth the calculated vertical stress under both tyres exceeded, however, the limit of $30 \mathrm{kPa}$ given by Grecenko (1989) for soils wetter than $70 \%$ of FC in the $0-0.3 \mathrm{~m}$ layer. The effect of low-profile tyres would have been greater had the ground pressure been less than the $82 \mathrm{kPa}$ used. For instance, reduction of the ground contact pressure to $50 \mathrm{kPa}$ decreased the calculated vertical stress down to $0.4 \mathrm{~m}$ depth considerably more than did the pressure of $82 \mathrm{kPa}$.

A traffic intensity of $300 \mathrm{Mg} \mathrm{km} \mathrm{ha}^{-1}$ compacted the soil more than that of $100 \mathrm{Mg} \mathrm{km} \mathrm{ha}^{-1}$, as reported by Koger et al. (1985) and Gameda et al. (1987). The increase in loading intensity did not, however, reduce either yield or nitrogen uptake significantly. This finding is not consistent with many earlier yield data from experiments where the soil was ploughed after the loading (Arvidsson and Håkansson 1994, Alakukku and Elonen 1995). One reason for the discrepancy results may be that, here, the increase in soil compactness was so small that it did not hinder crop growth markedly.

When the early summer was dry, irrigation increased the crop yield by $930-1990 \mathrm{~kg} \mathrm{ha}^{-1}$ and nitrogen uptake by $8-30 \mathrm{~kg} \mathrm{ha}^{-1}$. It did not, however, significantly affect the reduction in yield or nitrogen uptake due to soil compaction. By contrast, Elonen (1980) found that irrigation when the early growing season was dry reduced spring wheat yield losses due to clay soil compaction with a $3 \mathrm{Mg}$ axle load prior to seedbed 
Vol. 4: 445-461.

preparation. Likewise, Barraclough and Weir (1988) reported that irrigation reduced winter wheat yield losses due to subsoil compaction. The divergent results may be attributed to the fact that in the present study the seedbed in autumn-compacted plots was too coarse and hindered sprouting. Irrigation did not compensate for the effect of thin vegetation on the yield in compacted plots by increasing tillering, seed size or number of seeds per ear.

Despite compaction, the structure of this clay loam soil was good, and the soil was well drained and productive. Note also that relatively light machines were used for field work after the experimental traffic. Although the soil compaction reduced yields by $80-480 \mathrm{~kg} \mathrm{ha}^{-1}$ (on average $5 \%$ ), they were not small relative to those from many other clay soils in the surrounding area. One reason for the relatively high yields may be that the biopores and cracks present even in compacted soil provided pathways for root growth, despite the high penetrometer resistance of the soil. A greater relative yield reduction could be expected with soil compaction in less fertile soil, where the field work is done with heavier machines.

Soil compaction decreased nitrogen and grain yields in the same years. This is consistent with the findings of Phillips and Kirkham (1962) and Schuurman (1965) on mineral soils and small grain cereals. An equal dose of fertilizer was applied in all compaction treatments. Soil compaction lowered the efficiency of fertilization by reducing the nitrogen uptake of crops. However, because the fertilizer was not labelled, the results do not show the amount by which com- paction reduced the uptake of fertilizer nitrogen. It could be expected that, by reducing the nitrogen uptake of crops, soil compaction would also aggravate the harmful impact of crop production on the environment, for instance, by increasing denitrification.

\section{Conclusions}

(1) No cumulative effects due to annually repeated field traffic prior to autumn ploughing at the depth of compaction or yield losses were found. Except in the first year, the clay loam was drier than field capacity in the $0.2-0.3 \mathrm{~m}$ layer, which probably impeded further subsoil compaction.

(2) The reduction in trailer tyre inflation pressure from 350 to $150 \mathrm{kPa}$ by using low-profile tyres did not reduce compaction of the plough layer or yield reductions. It did, however, tend to reduce the intensity of compaction in the plough sole as a cumulative effect of four loading years.

(3) A load of $5 \mathrm{Mg}$ on a single axle and a tyre inflation pressure of $150 \mathrm{kPa}$ compacted a wet soil to $0.35 \mathrm{~m}$ depth. To avoid the risk of longlasting clay soil degradation due to subsoil compaction, single-axle loads of less than $5 \mathrm{Mg}$ should be used.

(4) Irrigation 1-2 times (18-33 mm per irrigation) early in the growing season did not significantly affect the reductions in the yield and nitrogen uptake of barley caused by soil compaction.

\section{References}

Akker, J.H.H. van den 1988. Model computation of subsoil stress distribution and compaction due to field traffic. Proceedings 11 th International Conference of ISTRO, 11-15th July, Edinburgh, Scotland 1: 403-408.

Akram, M. \& Kemper, W.D. 1979. Infiltration of soils as affected by the pressure and water content at the time of compaction. Soil Science Society of America Journal 43: 1080-1086.

Alakukku, L. 1996a. Persistence of soil compaction due to high axle load traffic. I. Short-term effects on the properties of clay and organic soils. Soil \& Tillage Research (in print). 
- 1996b. Persistence of soil compaction due to high axle load traffic. II. Long-term effects on the properties of finetextured and organic soils. Soil \& Tillage Research (in print)

- \& Elonen, P. 1994. Syksyn kuljetusajon aiheuttama savimaan tiivistyminen. Summary: Compaction of a heavy clay soil by transport traffic in autumn. Maatalouden tutkimuskeskus, Tiedote 17/94: 1-30.

- \& Elonen, P. 1995. Long-term effects of a single compaction by heavy field traffic on yield and nitrogen uptake of annual crops. Soil \& Tillage Research 36: 141152.

Alblas, J., Wanink, F., Akker, J. van den \& Werf, H.M.G. van der 1994. Impact of traffic-induced compaction of sandy soils on the yield of silage maize in The Netherlands. Soil \& Tillage Research 29: 157-165.

Andersson, G., Pidgeon, J.D., Spencer, H.B. \& Parks, R. 1980. A new hand-held recording penetrometer for soils studies. Journal of Soil Science 31: 279-296.

Arvidsson, J. \& Håkansson, I. 1994. Finns packningsskador kvar efter plöjning? Resultat från 21 långliggande făltförsök. Summary: Do effects of soil compaction persist after ploughing? Results from 21 Swedish long-term field experiments. Swedish University of Agricultural Sciences. Reports the Division of Soil Management 85: 1-31.

Aura, E. 1983. Soil compaction by the tractor in spring and its effect on soil porosity. Journal of Agricultural Science in Finland 55: 91-107

Barraclough, P.B. \& Weir, A.H. 1988. Effect of a compacted subsoil layer on root and shoot growth, water use and nutrient uptake of winter wheat. Journal of Agricultural Science, Cambridge 110: 207-216.

Blake, G.R., Nelson, W.W. \& Allmaras, R.R. 1976. Persistence of subsoil compaction in a Mollisol. Soil Science Society of America Journal 40: 943-948.

Bolling, I. 1987. Bodenverdichtung und Triebraftverhalten bei Reifen-Neue Mess- und Rechenmethode. Forschungsbericht Agrartechnik Arbeitskreises Forschung und Lehre Max-Eyth-Gesellschaft (MEG) 133: 1-274.

Campbell, D.J., Dickson, J.W. \& Ball, B.C. 1984. Effect of under-inflation of tractor tyres on seedbed compaction and winter barley establishment and yield. Journal of Agricultural Engineering Research 29: 151-158.

Chamen, W.C.T., Chittey, E.T., Leede, P.R., Goss, M.J. \& Howse, K.R. 1990. The effect of tyre/soil contact pressure and zero traffic on soil and crop responses when growing winter wheat. Journal of Agricultural Engineering Research 47: 1-21

-, Cope, R.E., Geikie, A. \& Stafford, J.V. 1985. A longterm experiment to compare the effect of different tyre/ soil contact pressures on soil and crop responses when growing winter wheat. National Institute of Agricultural Engineering, Silsoe, Divisional Note 1263: 1-43.

Danfors, B. 1974. Packning i alven. Summary: Compaction in the subsoil. Swedish Institute of Agricultural Engineering. Specialmeddelande S24: 1-91.

- 1994. Changes in subsoil porosity caused by heavy vehicles. Soil \& Tillage Research 29: 135-144.

Elonen, P. 1980. Soil compaction - a severe problem in Finnish agriculture. Swedish University of Agricultural Sciences. Reports the Division of Soil Management 60 : 41-45.
FAO. 1988. FAO/Unesco soil map of the world, Revised legend, with corrections. World Resources Report 60. FAO, Rome.

Gameda, S., Raghavan, G.S.V., McKyes, E. \& Theriault, R. 1987. Subsoil compaction in a clay soil. I. Cumulative effects. Soil \& Tillage Research 10: 113-122. -, Raghavan, G.S.V., McKyes, E., Watson, A.K. \& Mehuys, G. 1994. Response of grain corn to subsoiling and chemical wetting of a compacted clay subsoil. Soil \& Tillage Research 29: 179-187.

Grecenko, A. 1989. Some engineering aspects of preventing excessive soil compaction. Proceeding 4th European Conference of ISTVS, Wageningen, Netherlands 1: $62-68$.

Heinonen, R. 1960. A soil core sampler with provision for cutting successive layers. Journal of Scientific Agricultural Society of Finland 32: 176-178.

Hákansson, I. 1985. Swedish experiments on subsoil compaction by vehicles with high axle load. Soil Use Management 1: 113-116.

- \& Danfors, B. 1981. Effects of heavy traffic on soil conditions and crop growth. International Society for Terran-vehicle System, 7th International Conference, August 16-20, Calgary, Alberta, Canada. Proceedings 1: 239253.

Koger, J.L., Burt, E.C. \& Trouse, A.C. 1985. Multiple pass effects of skidder tires on soil compaction. Transaction American Society of Agricultural Engineering 28: 11-16.

Lipiec, J., Kania, W. \& Tarkiewicz, S. 1990. Effect of wheeling on physical characteristics of soils and rooting of some cereals. Zeszyty Problemowe Postepow Nauk Rolniczych 385: 105-114.

Lowery, B. \& Schuler, R.T. 1991. Temporal effects of subsoil compaction on soil strength and plant growth. Soil Science Society of America Journal 55: 216-223.

McGuire, C.F. 1986. Quality evaluation of distillrs' dried grain by near-infrared analysis. Cereal Chemistry 63: 155-159.

Milliken, G.A. \& Johnson, D.E. 1984. Analysis of messey data. Volume I: Designed experiments. Van Nostrand Reinhold, New York. 473 p.

Olsen, H.J. 1994. Calculation of subsoil stresses. Soil \& Tillage Research 29: 111-123.

Petelkau, H. 1984. Auswirkungen von Schadverdichtungen auf Bodeneigenschaften und Pflanzenertrag sowie Massnahmen zu ihrer Minderung. Summary: Effects of harmful compaction on soil properties and crop yields and measures to reduce compaction. Tag.-Ber. Akad. Landwirtsch. - Wiss. DDR, Berlin, Tagungsber. 227: 2534.

Phillips, R.E. \& Kirkham, D. 1962. Soil compaction in the field and corn growth. Agronomy Journal 54: 29-34. SAS. 1990. SAS/stat user's guide. CLM-Varcomp. Version 6. 4th Ed. SAS Institute Inc. SAS circle box 8000 Cary, NC 27512-8000. Vol. 2, pp. 891-1686.

Schuurman, J.J. 1965. Influence of soil density on root development and growth of oats. Plant and Soil 22: 352374.

Smith, D.L.O. \& Dickson, J.W. 1990. Contributions of vehicle weight and ground pressure to soil compaction. Journal of Agricultural Engineering Research 46: 13-29. Söhne, W. 1958. Fundamentals of pressure distribution 
Vol. 4: 445-461.

and soil compaction under tractor tires. Agricultural Engineering 39: 276-281, 290.

Vermeulen, G.D. \& Perdok, U.D. 1994. Benefits of low ground pressure tyre equipment. Developments in Agricultural Engineering 11: 447-478.

Voorhees, W.B. \& Lindstrom, M.J. 1983. Soil compaction constraints on conservation tillage in the northern corn belt. Journal of Soil and Water Conservation 38: 307-311.
-, Nelson, W.W. \& Randall, G.W. 1986. Extent and persistence of subsoil compaction caused by heavy axle loads. Soil Science Society of America Journal 50: 428433.

-, Senst, C.G. \& Nelson, W.W. 1978. Compaction and soil structure modification by wheel traffic in the northern corn belt. Soil Science Society of America Journal 42 : 344-349.

\title{
SELOSTUS
}

\section{Vuosittain toistuvan raskaan peltoliikenteen aiheuttama hiuesavimaan kumuloituva tiivistyminen}

\author{
Laura Alakukku ja Paavo Elonen \\ Maatalouden tutkimuskeskus
}

Maatalouden tutkimuskeskuksessa Jokioisissa tehdyssä kenttäkokeessa tutkittiin, aiheuttaako vuosittain toistuva syksyn kuljetusajo kumuloituvaa maan tiivistymistä ja ohrasadon laskua. Kenttäkoe tehtiin hiuesavimaalla, jonka savespitoisuus $(<2 \mu \mathrm{m})$ oli kyntökerroksessa $47 \%$ ja pohjamaassa $59 \%$. Sänkipellolla ajettiin neljänä peräkkäisenä syksynä traktori-perävunuyhdistelmällä. Yksiakselisen perävaunun akselipaino oli $5 \mathrm{Mg}$. Traktorin etuakselipaino oli 1,4 ja taka-akselipaino $3,3 \mathrm{Mg}$. Ajomäärä oli vuosittain 0 , 100 ja $300 \mathrm{Mg} \mathrm{km} \mathrm{ha}^{-1}$. Ajomäärä ajettiin sekä vakiorenkailla (rengaspaine $350 \mathrm{kPa}$ ) että matalaprofiilirenkailla $(150 \mathrm{kPa})$ varustetulla perävaunulla. Traktorin rengaspaine oli $140 \mathrm{kPa}$. Kun pellolla ajettiin, maa oli kenttäkapasiteetissa tai kosteampaa 0,2 m:n kyntökerroksessa. Ensimmäistä koevuotta lukuun ottamatta maa oli kyntökerroksen alapuolella $(0,2-0,3 \mathrm{~m})$ kuivempaa kuin kenttäkapasiteetissa. Lisäksi kenttäkokeessa tutkittiin alkukesän sadetuksen vaikutusta ohrasatoon. Osa kenttäkokeesta sadetettiin 1-2 kertaa kasvukaudessa. Kertasadetus oli 18-33 mm. Neljän koevuoden aikana määritettiin ohran siemen- ja typpisato. Maan mekaaninen vastus mitattiin ensim- mäisen kerran kahden tiivistysvuoden jälkeen ja siitä lähtien vuosittain.

Ajo $5 \mathrm{Mg}: \mathrm{n}$ akselipainolla tiivisti savimaan 0,35 m:n syvyyteen. Neljän vuoden keskiarvona maan tiivistyminen pienensi siemensatoa $5 \%$ ja typpisatoa $7 \%$. Tiivistymän syvyys tai satotappiot eivät lisääntyneet kumuloituvasti vuosittain. Maa tiivistyi mitattuun syvyyteen todennäköisesti jo ensimmäisenä koesyksynä, sillä myöhempinä syksyinä kyntökerroksen alapuolella $(0,2-0,3 \mathrm{~m})$ oli kuivahko kerros, joka todennäköisesti vähensi maan tiivistymisherkkyyttä. Kun perävaunun vakiorenkaat korvattiin matalaprofiilirenkailla, rengaspainetta voitiin laskea $57 \%$. Tämä ei kuitenkaan madaltanut tiivistymän syvyyttä eikä lieventänyt tiivistymän voimakkuutta kyntökerroksessa. Perävaunun rengaspaineen lasku ei myöskään pienentänyt satotappioita. Tulokset viittasivat kuitenkin siihen, että perävaunun rengaspaineen lasku lievensi tiivistymän voimakkuutta kyntöanturassa. Alkukesän sadetus lisäsi siemensatoa keskimäärin $34 \%$ ja typpisatoa $25 \%$. Sadetus ei kuitenkaan pienentänyt tilastollisesti merkitsevästi tiivistymisen aiheuttamia satotappioita. 